\title{
O Curso do Doutorado
}

\author{
João Arruda
}

Pertenci ao numero dos que entendiam ser um erro a criação do curso superior de altos estudos em nossas Faculdades de Direito. A atual geração a que pertenço só cuida no fôro da caça ao caso, de conhecer o último arresto do tribunal superior para com a decisão judiciaria se conformar, e ganhar a causa. Toda a atenção do prático está voltadia para as oscilações da jurisprudencia, sem ligar menor importância aos altos interêsses da comunhão social. Esta minha opinião da pouca aceitação que teria o curso se reforçou pela notícia da relutancia com que foi recebida em Buenos Aires tal inovação introduzida por Alfredo Palacios, e pelo modo por que os alunos aqui atentavam, ou antes, não atentavam, o que dizia da cátedra o professor. Com efeito, mesmo relativamente ao professor de processo, recorda-me que, em meu tempo, em 1881, fechávamos cuidadosamente as portas da sala para que ouvissemos todas as palavras preciosíssimas do professor Ramalho, já então de voz fraquíssima. Hoje, enquanto prelecionam os professores de processo, os rapazes jogam os dados, lêm romances, apostam sôbre o lugar do rosto onde o professor porá primeiro a mão, e tudo fazem menos tirar proveito das palavras do mestre.

Direi agora o que foi o curso do doutorado nestes dois últimos anos. Chamado, em meio do ano de 1932, para 
substituir o catedrático de Direito Romano, que se dizia partido para os Estados Unidos em missão científica, escolhi para o curso tudo quanto há de menos proveitoso imediatamente para o ganha pão: a História do Direito Romano. Digo imediatamente por compartir eu a opinião de CoNDORCET, adotada por COMTE, de que foram as especulações geométricas de homens de genio feitas há dois mil anos que permitiram ao marinheiro de hoje navegar com segurança conhecendo o ponto exato do oceano em que se encontra.

Notei porém na aula um silencio, uma atenção às minhas palavras a que eu não me achava habituado no curso do bacharelado. Atribuí à cortezia de moços de fina educação, que muito bem me conheciam do fôro, e que me favoreciam com a sua amizade. Sobrevindo a revolução, deixei a cadeira a que não voltei, mas nenhuma idéia podia formar do proveito de minhas lições.

Completo foi porém meu serviço no curso do doutorado que empreendi êste ano, na cátedra de Filosofia do Direito e julgo da maior importancia fazer dêle, ou melhor de seus resultados, um relatório, dizendo, em seguida, o que me parece digno de ser adotado para fomento dêstes estudos. Não quiseram os meus discipulos entrar em minha ordem de idéias, em conformidade com o pregado por Palacios: mostraram não desejar discussões, debates em aula, trabalhos denominados de seminario. Aumentou com isto meu desânimo, mas, pouco inclinado que sou a lutas, mesmo porque a minha idade convida ao descanso, ao repouso, aceitei o papel que me era imposto de prelecionar durante os $50 \mathrm{mi}-$ nutos regulamentares.

Seja, neste momento, indicado o fruto colhido. Nos exercicios práticos que me ofereceram os alunos, durante a primeira fase do curso, notei que se limitavam a repetir o que dissera a cadeira, a ilustrada cadeira, na formula acadêmica, a resumir a sebenta, para me servir da expressão de Castelo Branco. Apareceu algum raro trabalho com idéias originais. No segundo período, porém, outra foi a orientação dos trabalhos. Havia originalidade em quasi todos, mostravam os 
alunos grandes estudos, investigações, leitura de obras novas, conhecimento de doutrinas sociais que germinam neste momento trágico da vida da humanidade, crítica viva das inovações em assuntos criminais e econômicos, indagações filosóficas, frisando por vezes os altos problemas da Metafisica, mostras de sêde de saber, argumentos evidentemente originais, e não colhidos em livros, e, mais que tudo, uma tendência à sistematização, a constante idéia, quiçá exagerada, de organizações arquitetônicas das cousas sociais, ou, noutros termos, a tendência utópica, hoje algum tanto decaída. Se não alcançarem meus discipulos reformar o mundo, mostraram, em suas traças do edificio social, muita cousa aceitável em pról da humanidade sofredora de hoje. Longe estava eu de pensar, ao falar àqueles moços silenciosos, que lançava uma semente proveitosíssima, a germinar no cérebro de homens de boa vontade, orientadores das futuras gerações. Nunca pensei fôsse tão proveitoso o curso que eu recebera com tanta antipatia e em que trabalhava só pelo hábito de cumprir mecânicamente o meu dever. Raro foi o aluno que se contentou no $20^{\circ}$ periodo com resumir as lições ouvidas, durante o curso: quasi todos puseram muito de sua lavra, e êstes sempre revelando talento, espírito investigador, originalidade. Auguro vitória notavel na defesa de teses que deverão fazer pròximamente.

Julgo, pois, mudando de opinião, visto como supunha que a alta cultura deveria ser um empreendimento individual, e não coletivo, dever ser mantido o curso de doutorado, de cuja supressão ora se cogita sèriamente, chegando-se a falar em ser de muito custo, excessivamente dispendioso! Economia em estudos!.

Mas chego ao termo dêste pequeno relatório: que cumpre fazer para animar o curso? Parece-me que seria utilíssimo, neste tempo em que tanto se fala de profissionais habilitados (vulgarmente os técnicos), dar preferência aos doutores, pondo em plano inferior os bachareis. No ramo criminal, cumpre preferir doutores do curso especializado em defesa social contra o crime, para as promotorias, juizados do crime 
e mais serviços dependentes da cultura do Direito Penal. Direi, de passo, que uma das brilhantes dissertações do $2 .^{\circ}$ periodo versava justamente sôbre a necessidade de serem os juízes do crime técnicos neste ramo de defesa social. Para os do curso especializado em ciências econômicas, neste tempo em que se sustenta com tanto ardor ser o fator econôImico o único que anima o movimento social há colocação para os técnicos nos mais variados emprêgos, e com aproveitá-los ficaria a sociedade senão a salvo, ao menos muito menos sujeita aos erros diários que cometem os govêrnos em prejuizo da riqueza pública e do bem estar dos membros da comunhão social: desde o Ministério da Fazenda até a mais modesta delegacia fiscal, quanto lugar há nas repartições que poderia ser desempenhado por homens conhecedores das verdadeiras necessidades do povo. Enfim, no que diz respeito à distribuíção da justiça, à animação e manutenção da fôrça especifica do organismo social, claro é que a preferência para os juizados cíveis, para as curadbrias, para a feitura das leis (e como, em geral, são hoje elas lastimàvelmente redigidas!), para o magistério, e mesmo para os cargos mais modestos do notariado, sempre deveria ser dada aos moços que tiveram o curso de alta cultura.

Sáio da Faculdade, após 27 anos de serviço desempenhado na medida de minhas fôrças, e, por vezes, acima delas, mas posso afirmar que nenhum trabalho me pareceu mais proveitoso do que o curso que fiz êste ano para preparo dos futuros doutores em Direito, e, com conciência, devo afirmar que erro e grande será pôr por obra o plano de extinção dêste ramo de estudos por simples medida econômica. 